\title{
Media Watchdogging and the Crisis of Governance in Nigeria's Fourth Republic
}

\section{Gidado Taofeek Oluwayomi}

Department of Sociology and Anthropology, Faculty of Social Sciences, Obafemi Awolowo University, Ile-Ife, Nigeria

\section{Email address:}

ygidado@oauife.edu.ng, yomigidado@yahoo.com

\section{To cite this article:}

Gidado Taofeek Oluwayomi. Media Watchdogging and the Crisis of Governance in Nigeria's Fourth Republic. Humanities and Social Sciences. Vol. 9, No. 5, 2021, pp. 122-135. doi: 10.11648/j.hss.20210905.11

Received: July 19, 2021; Accepted: August 7, 2021; Published: September 3, 2021

\begin{abstract}
There is an issue that most scholars would reach consensus on: the significance of the media for democracy and good governance. This paper's point of departure is that the media provides the basis for popular participation in democratic politics, and that democracy loses its essence without a vibrant and independent media. Unarguably, the media provides access to information in a democracy, and provides a check on elected state/public officials. Without an independent and robust media, democracy would be an endangered project. In Nigeria, the media is the watchdog on both the government and the society. Section 22 of the 1999 Constitution (as amended) details the responsibility of the media to hold the government accountable to the citizens of Nigeria. The media is generally considered the fourth estate of the realm, imbued with omnibus responsibilities to inform and educate citizens with a view to engendering democratic inclusion and accountability of the government to the people. Therefore, a free and incorruptible media would enable informed citizenship and engender good governance. However, this paper contends that the environment in which the Nigerian media operates circumscribes it from delivering its optimal responsibilities to the society and the government. The paper further identifies the factors that constrain and incapacitate the media from being an efficient and effective watchdog on both the government and society. The paper posits that despite the fact that the return to civil rule in 1999 was expected to facilitate the independence of the media and a greater freedom of expression than Nigerians had experienced under military rule, the reality is that the media was more effective during military rule in its watchdog functions on both the government and the society. Thus, the paper contends that the media have performed less creditably under a civil rule than it did under a military regime that had governed Nigeria, prior to 1999. Conclusively, the paper argues that without a strong and independent media, good governance and an inclusive society would remain elusive.
\end{abstract}

Keywords: Watchdog Media, Good Governance, Corruption, Agenda Setting, Democracy

\section{Introduction}

The media is an important institution that protects public interest, representative democracy and demands accountability in both public and private spheres. It also activates political consciousness amongst citizens with a view to engendering an inclusive society. It is for this reason that some studies have concluded that a strong, robust, free and incorruptible media is an indispensable institution to building representative democracy, functioning electoral system and good governance [1]. By the generic use of the word media, this paper restricts discussions to both the print and electronic media, regardless of whether they are owned and controlled by the public or the private.

The media was coined in early twentieth century to describe what was regarded as a new social phenomenon that became a significant feature of the evolving contemporary world, built on the foundations of popular democracy and industrialism [2]. In spite of the centrality of the media to democracy and governance, sociological researches have ignored media studies on the claims that it lacked sufficiently 'serious' subject matters that demand a distinctive attention [3].

Unarguably, free and independent media has somewhat evolved from the western democracies [4] and have been stronger in developed democracies than both developing and stunted democracies. It is also pertinent to adumbrate that democracy is a contested term with ubiquitous interpretive element that is rooted in the history and culture of western nations. Regardless of the level of the development of a society, the media is an important institution that 
disseminates information and mediates between the state and the civil society [5]; even though, the nature of interaction between democracy and the media remains "... open and controversial" in the contemporary global politics [4].

The essence of democracy would be defeated without a robust and independent media that puts the government in check. This is because the media is the breadth of democracy for two major reasons: the media ensures citizens make responsible and informed choices rather than act out of ignorance or misinformation, especially during elections; and, second, the media gives information that provides a "checking function" that ensures elected representatives defend their oaths of office and implement the aspirations of the electorate [5]. Hence, the major democratic role of the media is to act as a check on the state [6] and to activate a politically conscious citizenry that protects the state. For the media to be effective in playing these roles, there are three pertinent questions that must be addressed and resolved: "who wields the power of communication in a society, who has access to the means of communication, and who is communicated to?" Once these questions are not resolved in the public interest, it means the responsibilities of the media would be compromised and become perverse with dire consequences for democracy.

In Nigeria, the media is largely controlled and owned by the state and the ruling elite. This feature and constraint has largely affected the responsibilities of the media to defend public interest, put the government in check and disseminate information to the citizens. It is not in contention that the media plays a critical role in democracy and democratization [7]. However, the roles the media would play in deepening democracy would depend on the structure of power, political culture, the configuration of the media, market pressure, organizational constraints, ideology and personal inclinations [4]. For the media to be important to the process of curbing corruption and engendering social accountability mechanisms [8], it has to be insulated from politics and political control. For this reason, the degree to which the incapacitation of the media has contributed to the crisis of democratisation in Nigeria needs to be further explored and interrogated in scholarship.

A cursory assessment of the media might conclude that the Nigerian media has done well since the return to civil rule in 1999. But the reality is that there has been a gap in the responsibility of the media to make government more accountable to the citizens, in building an informed citizenship that would demand greater accountability from the government and in setting the agenda for conversations that would strengthen public policy. Therefore, the constraint of the media has engendered a poor culture of public discourse that is mainstreamed by primordial expressions and the mobilization of a politically unreflective citizenry that often succumb to elite and media manipulation. Other factors that lead to the incapacitation of the media are rooted in media ownership, poor remuneration, culture of bribe, lack of resources, lack of training, irresponsible investigative journalism, and the threat to life that restrain media practitioners from unearthing the truth.
In spite of the role of the media in strengthening governance systems, exposing corruption and in building informed citizenship, this paper posits that the media has failed to be an effective watchdog on the government. It is argued that the failure of the media cannot be extricated from the failure of governance, the deepening crisis of democratisation and the poverty of public discourse on social policy in Nigeria. The assumption that the media is presumed to be doing its responsibilities in the public interest is tenuous when we appreciate that those who own media outfits in Nigeria express political partisanship and economic interest as the primary motivation for setting up a media. The issue of establishing the media for reasons of education and the protection of the democratic space is of little or no consideration to media proprietors in Nigeria.

Incidentally, the structure of the Nigerian state and the political economy of the environment in which the media functions create a context that compromises the responsibilities of the media to the government and the society. However, it is difficult not to excoriate the media for the extant deepening crisis of democratisation and bad governance in the country. The large pool of uninformed citizens and a disconnected government underscores the reality that the media has not been quite responsive.

In light of the above, the media is important to engendering good governance and citizens' civic participation. A vibrant media would inform and educate citizens to shun primordial expressions on issues relating to civic participation and national discourse. A scrutiny of the editorial interventions of the media sometimes reveal political partisanship that veils an outright expression for primordial cleavages in the society. The nature of public discourse that tends to undermine a pan Nigeria conversation is often given a space in media coverage/reportage. The inability of the media to promote conversations around the nation building project underscores the salience of the challenges that confront the media. Those who have created the problems that afflict the country are the same people who control the media. There is a growing assumption that the media has become a part of the problem that afflicts the country. It is obvious that the limitation of the media has made the institution to become a component of democratic debate.

\section{The Role of the Nigerian Media in the Evolution of the Nigerian State and Democratic Struggle}

The Nigerian media played an important role in the struggle against colonial rule and military dictatorship. In Nigeria, the idea of the media as the watchdog of the government dates back to the era of decolonization; though, the media had earlier years of responsibilities in other more developed societies.

In colonial Nigeria, the media played crucial roles in the struggle for the decolonization of governance. In post-colonial Nigeria, it also played important roles in the struggle against the military regime and authoritarian civil rule. Between 1960- 
1966 and 1979-1983 under which Nigeria had a truncated experience with civil rule, the media was active in setting the agenda against authoritarianism, corruption, maladministration and bad governance. Also, during the struggle against military rule, the media provided the anchor for activities against the military and the restoration of civil rule. The military regimes of General Gowon (1966-1975), Generals Muritala and Obasanjo (1975-1979) General Muhammad Buhari (19831985), General Ibrahim Babangida (1985-1993) General Sanni Abacha (1994-1998) and General Abdulsalam Abubakar (1998-1999) came under very trenchant opposition that the media articulated: it played very popular roles in the struggle against the military, and in creating popular sentiments and support for the return to civil rule in Nigeria.

In Nigeria, the courageous role of the media in providing a voice and a platform against the military hastened the decision of the military to return the country to civil rule. The constant resort of the military hierarchy through the Supreme Military Council or the Armed Forces Ruling Council to endorse proscription and withdrawal of licenses as a strategy of containment against trenchant and independent newspapers reveal the courageous roles of the media. The media houses that offered independent narratives to government policy were hounded by the military government Newspaper platforms such as News Watch Magazine, The Guardian, The Tell, The News and The Punch came under heavy repression of the military brass, especially under Generals Babangida and Abacha regimes for providing independent narratives on stories that were considered by the government to be too sensitive and "subversive".

What is instructive is that during the period of military dictatorship in Nigeria, the media provided a platform for the mobilization of popular sentiments against military adventurism in politics. In other words, the media served as the conduit for vital political information that enabled citizens to participate in meaningful public participation. The media mobilised the citizens to be involved in the processes of state-nation building project. The linkage between the media, rights activists and the civil society during the regimes of Generals Ibrahim Babangida and Sanni Abacha saw to the eventual collapse of such iron clad regimes that almost succeeded in turning Nigeria into a fascist state. The core responsibility of the media to funnel citizens' expectations to those in government, monitor the government to ensure public safety is guaranteed, and educate and mobilise citizens for collective participation in governance were achieved during this defining period.

It is pertinent to point to the resilience of the media under General Ibrahim Babangida's military regime: the media provided the platform for the education of the citizens on the policy content of the World Bank/IMF loan, its implications for the quality of life, and articulated the opposition of Nigerians to the World Bank/IMF loans. It also gave publicity to the voices and opposition of the Nigerian students, scholars and workers to pro-imperialist policies of the Obasanjo and Babangida military regimes. It played significant opposition roles to the windy electoral transition programme of Generals
Ibrahim Babangida and Sanni Abacha regimes. Sadly, post 1999 observations of media reportage in both print and electronic media institutions reveal a less much edifying roles in public education and engagement.

Since the return to civil rule in 1999, the media appears less trenchant in its watchdog activities over the government and the society (as it did under the military regimes). In other words, the media has not been very vociferous in its watchdog activities, namely, (1) ensure that government is made more transparent and answerable to the citizens; (2) in setting the agenda for development and good governance; and (3) in highlighting policy failures, protecting public interest and in exposing corruption in the government. If the media is circumscribed in creating conditions that would reflect the assertion that "public discourse should be carried on in order for a community or nation to solve its problems" [1], then the essence of the media would have been defeated. The media has failed to provide the forum for public debates in educating citizens about policy implications and alternatives to government policies for the purpose of resolving societal problems. The core reason for the lame duck disposition of the media cannot be extricated from the ownership of the media, market considerations and the corruption of media practitioners.

\section{Nexus Between Government and the Media}

The relationship between the government and the media has always excited some controversies. One of the perspectives to these controversies raises the proposition for the need to whittle down the powers and responsibilities of the media for the purpose of achieving national integration and cohesion. The other perspective offers a counter proposition that it is better to have a strong media to curb the excesses of the government.

There are two contrasting narratives to the importance of the media to the government and the nation-state building project. The first narrative explains that the media is an instrument of division in fractured and heterogeneous societies. The argument here is that the media should be censured to ensure that government works with little or no distraction to engender a cohesive society. This view was promoted by Chancellor Qin of the unified Chinese state. The other narrative is that the media is a critical institution that helps to engender and deepen responsive governance outcomes. In other words, the media is inevitable to the successful political outcomes of a government. This view was promoted by Thomas Jefferson who espoused that it is better for a society to have a media without a government than a government without a media The logic that drives through this school is that a responsible, responsive and active media would provide the bulwark to the arbitrariness and impunity of government; and also helps in building an inclusive society through participatory democracy. Hence, the media is so important to governance systems and also arbitrates between the civil society and the government. 
It needs to be appreciated that any conversation on the role of the media in governance would stir debates about effectiveness and values of the media to the government. For this reason, the way the media frame public issues would either lend support for public debate or create a resentment and antagonism for government policy. Thus, debates on the need for a strong and plural media that is freed from excessive governmental regulatory control conveys the argument that the media would undermine the efficiency and stability of government; even when there is an appreciation of the role of the media to ensure that there is accountability and responsiveness in government's actions. On the other hand, a government with a lame duck or feeble media conjures the impression that the government would be driven by impunity, arbitrariness and corruption.

It is important to aver that the success of the media would depend on both exogenous and endogenous factors such as excessive restrictive regulations of the government, hostile environment, threat to life, uninformed and uncritical citizenry, market and economic considerations, ownership control, political partisanship of the management, unprofessional and unethical conduct of media practitioners, corruption of/by journalists, poor remuneration, and other factors that constrain the media from performing its duties diligently. Whatever the role of the media is or ought to be, the reality is that the media embodies resources that can be deployed to either demote or promote democracy (4). On the issue of values and roles, the media is expected to engender a governance culture that would lead to political outcomes that deepen democracy and respect for political freedom in an inclusive society. The media would also undermine democracy if it deliberately and intentionally compromises ethical, temperate and balanced reportage that distorts the construction of social realities with a view to fostering narrow interest. Once a media becomes claustrophobic and dishonest in the articulation of public policy, it undermines the capacity of the state, erodes the legitimacy of representative government and destroys the basis of democracy as a political system of governance.

It is not in contention that the media plays a decisive role in the construction of social realities, and in perceptions over issues around the definition of the situation as a result of its responsibilities to educate and disseminate information that will excite informed debates in the society. Therefore, the five indicators of good governance, accountability, lack of corruption, transparency, responsiveness and inclusion identified by [9] can only be engendered when citizens can engage in meaningful and active civic participation in public life. Sadly, since the return to civil rule in 1999, the Nigerian media rarely demonstrate the execution of its responsibilities to engender the nurturing of a democratic inclusive culture and society. The pervasive high level of acrimony and cynicism in the Nigerian society in which public discourse is often driven by primordial expressions that touch on the fault lines of the country is largely a creation of the media that is manipulated by a bankrupt, opportunistic and corrupt political and economic class/elite that controls the media, defines its essence and perverse its responsibilities/objectives.

The media provides the barometer to measure the health of a democracy, and it is an instrument for engendering good governance. However, there is some controversy as to what should be the role of the media in governance and in nation building. Government on one hand, and the media and the civil society on the other hand, have largely differed on what should be the role of the media. The most recent example of such mistrust is the suspicion over the intention of President Buhari's government to tinker with the laws regulating both the print and electronic media. The media and the civil society considered the reasoning of the government as a subtle attempt to gag the media. The officials of the government also think the media has become a divisive institution that is used by opposition elements to undermine the legitimacy of the government. In spite of this divergent perception, there is a shared consensus between the civil society and state officials that the media needs to be more proactive in setting the agenda that would address the plethora of societal problems in which the Nigeria state is immersed.

\section{Corruption of/in the Media, the Emergence of the Social Media and National Security}

The Nigeria media operates within the context of a political economy that makes media practitioners vulnerable to corruption. Thus, corruption is a consequence of the ecology in which media practitioners find themselves. The specific forms of corruption that thrives in the Nigerian media ranges from taking bribes that is known as "brown envelopes", placing adverts to influence stories, extortion of both public and corporate officials that is sometimes practised by journalists for the purpose of suppressing/distorting stories that could impugn either the integrity of both public and private officials or that could damage the reputation of either the government or the private institutions. The problems of corruption in the media is facilitated by a crimogenic (crime induced environment) and asphyxiating context in which the media operates and which resultantly makes the practice of investigative journalism and evenhanded reportage cumbersome.

It is instructive to mention that the ownership of the media poses a serious challenge to the quality of reportage that is done by the media. For example, proprietors of media houses who enjoy cordial relationship with a government in power ensures that their media houses are either not critical of government policies or expose the corruption in government, especially when such media houses have unassailable evidences. Sometimes too those who are in the opposition to the government in power and who have established media houses often use such platforms to publish (un)true stories that they would not have published if they had a cordial relationship with the government in power. Beyond the specific forms of corruption mentioned above, inadequate training and poor technical skills, poor professional standards, limited financial resources, opaque or government-controlled 
ownership structures and poor legal frameworks (Transparency International: Anticorruption Resource Centre) and poor salary and working conditions are other pertinent factors that have engendered corruption in the media. In general, the media have been hobbled by its ownership problem, profit goals, partisanship, poor working conditions of journalists, primordial factors that speak to the fault lines of the Nigeria nation as well as the overbearing influence of the government on its operations.

The yearnings of the citizens for objective and quality information seems to have facilitated the development of the social media. In other words, the failure of the mainstream conventional media to report the truth (especially on government activities) informed the lack of confidence in conventional media institutions. Therefore, the emergence of the social media is a reflection of citizens' determination to bring accountability and transparency into the government, engender good governance and a just, inclusive state. Citizens tend to believe that the narratives of the traditional media are distorted and largely compromised to serve narrow interest of those in government and the economic class. Hence, the resort to the social media as an alternative platform for generating and disseminating information which are either considered too sensitive for publication by the traditional media or are suppressed and/or distorted by the traditional media for reasons informed by narrow interest. Incidentally, the development of the social media is also a consequence of the logic of globalization and the consequent emergence of a digital world that has created conditions for a global village and global culture to exist. In other words, both endogenous and exogenous factors facilitated the development of the social media in Nigeria with consequence(s) for information management and governance.

Incidentally, the quality of information in the social media sometimes poses a challenge for national integration and national security. Admittedly, the quality and nature of discussion in the social media is largely poor and often mainstreamed by primordial expressions that are couched in hate speech. The context in which the social media operates seems to be a source of its affliction as it is for the mainstream traditional media. Those who have control of the mainstream media have also extended their influence on the social media. Sometimes, the use of the social media for unhealthy reasons such as disseminating false stories ostensibly to cause disaffection and promote hate speech suggest that the social media is controlled by some powerful forces, corrupt political elites and their protégés for political agenda. The negative role the social media sometimes play provides a justification for government's effort to regulate the social media. Occasionally, the activities of the social media tend to undermine national security and national integration. The recent decision of the government to ban the operations of Twitter in Nigeria on the basis of government's claim that its activities undermine national security is a case in point. A perusal of the contents of some blogs and social media hubs as well as the use of WhatsApp messages have facilitated the use of divisive and untrue narratives that tend to spread disaffection and promote hate speech in a heterogeneous society like Nigeria. This may explain the rationale for the government's decision to regulate the perceived excesses associated with the media. Expectedly, the media has responded with a push back to the effort of the government to regulate its activities. The action of the government was described by the media as brazen and authoritarian and the controversial bills, namely, the Nigerian Broadcasting Commission (NBC) and the Nigerian Press Council (NPC) Act amendment bills were described to be efforts to censor both the conventional media and the social media. If the media is the oxygen of democracy, the bills would be interpreted as acts that would stifle press freedom and might invoke public backlash. The decision of the government has been roundly condemned and considered to be an assault on the media. The joint release from the Nigerian Union of Journalists (NUJ), Nigerian Guild of Editors (NGE) and Newspaper Proprietors Association of Nigeria (NPAN) demonstrated the resentment of media practitioners and stakeholders to the effort of the government to regulate the media. On Monday, July 13, 2021, all the leading newspapers in Nigeria devoted their front pages to protest against what is considered an attack on press freedom, under the banner-'Information Blackout'. Also, the Premium Times, a leading online newspaper in Nigeria, in an editorial on July 26, 2021, argued that the effort of the government would "end up strangulating the media...".

It is not in contention that government has the exclusive responsibility to protect life and property; and no responsible government would want to allow disorder within the territory it governs or watch its legitimacy to be eroded. There is no doubt that the social media needs to be regulated to address the excesses of those who use it to spread disaffection. The media indeed needs some regulation to enhance objective reportage and enhance ethics and professionalism. However, the issue and emphasis should not be with regulation but the nature of the regulation and how the process of the regulation is pursued. The process of regulating both the media and the social media must be inclusive and in the public interest; and the content of the regulation must be the result of collective engagement. The cynicism that develops in reaction to the effort of the government is as a result of the deficit trust for successive governments over its inability to provide good governance and adhere to the constitution. Hence, some citizens, groups, civil society organisations and the media dub the effort of the government to regulate the social media as a subtle attempt to curtail the freedom of expression and right to access information, which is enshrined in Section 39 of the Nigerian Constitution. For example, the statement issued by the Socio-Economic Rights Accountability Project (SERAP) to drag the Federal Government to court over its decision to ban Twitter in Nigeria is a good case that chronicles the mistrust for the intention of the government.

The mutual suspicion between the government and the media is a consequence of the veiled animosity between the government and the media. The government suspects the intention of the media to lay claims to ethics and 
professionalism when it publishes a story government considers too sensitive for national security. In instances when the media publishes true stories on government officials or transactions in government, successive governments too have been intolerant to opposing views by using the power invested in the state to arbitrarily shut down perceived critical media platforms, withdraw its licenses, deny journalists the right to cover government functions and sometimes detain journalists in reaction to stories that are either untrue or half true and sometimes out-rightly false. The contention of the government is that journalists should be discrete in the publication of stories that are too sensitive for national security. The reason for the government to ban the operation of Twitter in Nigeria is not unconnected with government's belief that the activities of the Organisation undermine the national security of the country, and the perception that the platform is becoming a haven for the opposition and ethnic irredentists to haul scathing blistering criticism against the government. But the explanation of the government, even though very genuine on the surface, has not convinced some citizens and the civil society that the intention of the government was rational, genuine, noble, and altruistic. Virtually all the major print newspapers in Nigeria did an editorial on July $13^{\text {th }}, 2021$ condemning the attempt of the government to regulate the media. The content of the editorial revealed the hostility towards the effort of the government to regulate the media. It is instructive that disagreement over some issues of policies between the government and the media sometimes account for the differences to have a common understanding on the evolution of policies for national development and national security.

In a clime like Nigeria in which governance has largely been disconnected from the citizens for reasons associated with the dismal performance of successive governments, the media needs to discharge its responsibilities to the society by setting the agenda for development, educating the citizens about the policies of the government, highlighting the consequences of government policies to citizens and ensuring citizens have a good appreciation of the views canvassed by government officials. The media has largely failed in meeting those goals that provided a basis for its existence. The context in which the media operates is an implicating factor in its failure.

\section{Media, Accountability, Environment and Good Governance}

Studies have concluded that transparency and accountability in government increases access to information [10]) and that the media plays an important role in the credibility of the electoral process [11]. An avalanche of studies has have equally shown some correlation between freedom of the press and control of corruption in public institutions [12, 13]. Given the criticality and uniqueness of the media to the process of engendering good governance, there is little appreciation by successive Nigerian governments to provide a conducive environment for the media to thrive and collaborate with the government on its avowed intention to curb corruption and engender good governance. Even though, former President Goodluck Jonathan had taken some bold steps to enact the Freedom of Information Bill to help both citizens and the media secure information on government and public officials, the reality is that government officials have made the process of securing information on government business difficult under the guise of 'national security' or the 'protection of public officers'. It also appears that the goals for the enunciation of the Freedom of Information Bill was more political than an effort to create an environment for the media to operate and for government to be made more transparent.

In the light of the reluctance and grudging acceptance of Nigerian public officials who occupy key strategic positions in government to enforce the Freedom of Information Bill accented to by former President Goodluck Jonathan, government business and governance is still made secretive and opaque. For example, during the administration of former President Jonathan, the African Centre for Information and Literacy (AFRICMIL), an Abuja based nongovernmental organization, headed by Chido Onumah, one of Nigeria's civil rights activist, approached the Code of Conduct Bureau (CCB) for the declaration of asset of former President Jonathan and his Vice, Architect Namadi Sambo. The CCB declined the request of AFRICMIL to avail it the asset declaration of the President and his Vice. The letters written by AFRICMIL, originating summons and reliefs to the court are provided in the appendix to this paper to demonstrate that the government is less concerned with the spirit and noble goals of the Freedom of Information Bill. It was evident that the reluctance of a strategic institution of government like the CCB could be construe to mean that the government was only paying lip service to the implementation of the Freedom for Information Bill and just seeking political relevance.

Obviously, there is little government is doing to make governance more transparent and accountable to the citizens through the Freedom of Information Bill accented to by former President Jonathan. The incumbent President, Muhammad Buhari, in a public function, had stated that national security should take precedence over the freedom of the press to publish information on the government. The President's position was further amplified by the Minister of Information, Alhaj Lai Mohammed, who reiterated concerns over the responsibilities of the media in a context of growing insurgency, banditry and criminality to be very discrete in its reportage. It must be admitted that the extant level of insecurity in the country as a result of terrorism, banditry and abduction provide a reasonable justification for the government's view that the media should be more sensitive in its reportage to protect national security. However, it is not impossible for the government to use its discretion to (de)construct and profile acts that constitute 'national security' and 'national interest' so as to shrink the social space for criticism, exposing corruption and in providing a convenient ambience to deal with perceived and imaginary political opponents.

It is also important we aver the reason for why the government seems less enthusiastic about the independence 
of the media. The political economy of the Nigerian state compels government to be driven by impunity, and to act in breach of its laws. Essentially, the Nigerian state is a creation of colonial force. The hostile manner in which the State relates to the media and the lip service it pays to the freedom of independent expression is a reflection of the bestiality of its evolution and origin. In spite of the legal creation of the Freedom of Information bill, government officials still conduct government's business in secrecy and frowns at any effort to bring transparency into government. The secrecy that often surrounds government encourages public officials to become corrupt. On the other hand, the media also has its own challenges: the environment in which the media operates as well as its ownership encumbers it to make government accountable and transparent by providing critical information to the citizens. The reason for this is that most of the media moguls in Nigeria have political affiliation either with the political parties or the government in power. This relationship is largely responsible for the internal censorship in the media and the lacklustre performance of the media to inform citizens. Sometimes too the fear of government taking stern measures that may affect their business often lead to veiled internal censorship of what to publish or not to publish against the government and public officials, ostensibly for the protection of pure economic motives of the media proprietors/owners or sometimes for purposes related to the urge for primitive accumulation.

The issue of internal censorship appears more recurring and pernicious for media freedom than the action of the government to deliberately censor the media. Internal censorship evokes less resentment than the effort of the government to regulate the media because it is internally done in a systematic and covert way. It needs mention that there has been less obvious government censorship of the media since the return to civil rule than we had during the military that governed until 1999. However, it is pertinent to state that the censorship that exist since the return to civil rule has been more systematic, less obvious and more recurring than we had under the military. This is because there has been internal censorship of the media by those who have established media platforms for political motives and economic gains. Some of the media owners are either politicians or have cordial relationship with those in government and often receive patronages from the government. Restrictions on the media induces corruption in the government since government officials would conclude that the cost of paying for corrupt practices is low. Internal censorship that is occasioned by economic and political influences on the freedom of the media are more inimical than detrimental regulatory laws [12] that are formulated by the government. Incidentally, the travails of the media is compounded by the activities of media owners' who are politicians out of government but who use such platforms to publish stories that they would not have published if they were in government. For example, there is a swirling perception that the criticism that is hauled by a section of the media against the President Muhammad Buhari's government is anchored by major opposition politicians who have some leverage on such media platforms. The African Independent Television has been a vocal critic of the Buhari's administration for reasons that might not be unrelated to the fact that its founder Chief Raymond Dokpesi is a frontline member of the major opposition Peoples Democratic Party (PDP). But during the administration of former President Jonathan, the AIT was literally the mouthpiece of the PDP led government. Stories that are crafted by the media as a result of political influences often pose serious credibility problems for the media in Nigeria.

Beyond the question of censorship is the poor working conditions and salaries of journalists who find it difficult to resist the "brown envelopes" or promises of juicy appointments in government agencies for themselves or their relations. Sometimes journalists are offered petty contracts to influence stories and compromise their professional responsibilities. Journalists do write stories that are not reflective of the actual situations in government. In order words, they either tend to cover up corruption in government circles or often underreport the magnitude of corruption or even exaggerate the scale of corruption in government circles for crude gains. It is sometimes difficult to have some confidence in stories that are written by journalists who have taken bribes. Corrupt practice amongst journalists in Nigeria has become a common practice. It appears there is little or nothing that the regulatory bodies have done to address corrupt practice amongst journalists. It is also too evident that the Nigeria Union of Journalist have winked at this disturbing practice amongst its members. The reason for this conclusion is that the spate of corrupt practices amongst journalist far exceed the punitive actions against erring members and that punitive actions against erring members have not gained traction in the public space.

In addition, the arbitrariness and impunity that characterized government and sometimes compel it to engage in state sponsored assassination of journalists that are perceived to be too bold and recalcitrant also send some fears into some journalists to strike a balance between professionalism and native wisdom (protecting their lives). The assassination of one of Nigeria's most courageous and cerebral columnist and former Newswatch Editor-in-Chief, Dele Giwa, and the inability of the Nigerian government to unravel and identify those behind the assassination that was executed on $19^{\text {th }}$ October 1986 is salient and instructive. It has always been a scary experience for journalists who want to demonstrate courage and defend professionalism to unearth the truth. The late human rights lawyer and right activist, Chief Gani Fawenhinmi, held a strong belief that Dele Giwa was assassinated by the military government of General Ibrahim Babangida. Chief Gani Fawenhinmi's effort to put retired Col. A. K. Togun, Deputy Director of the State Security Service (SSS), General Haliru Akilu who was the Director of Military Intelligence and Ismaila Gwarzo, the Director of State Security Service on trial for the assassination was unsuccessful.

Another probable issue that has made the media less 
vociferous in its effort to fight corruption and bad governance is the perceived accommodating attitude of the citizens to corruption and the lack of political will to mobilise against bad government. This seems to provide a convenient context for the lethargy amongst media practitioners to mobilise public sentiments against corruption and impunity in government. Indeed, some studies have established that a "close examination of several recent instances of press sleuthing with widely heralded payoffs indicates that the media often deserve less credit than previously believed for detecting public wrongdoing and fostering correction"[14]. If the media develops lethargy to mobilize against corruption and foster accountability in government for reasons associated to either its corruption or what is regarded as the ephemeral nature of public reaction to reports on corruption [15], it would be difficult to engender public accountability, build public participation in governance and engender democratic inclusion. Sometimes the decision of the media to invent and orchestrate false campaigns and mischievous stories against the government are motivated by the desire to capture public attention and increase sales [12]. The unprofessional practice of media practitioners is responsible for the low confidence that people sometimes express in media stories on corruption.

The critical role of the media in informing the public and presenting diverse narratives with which to stimulate public participation and support political competition by mounting pressure on politicians to stand against corruption [13] can be defeated if the media is corrupt in the execution of its functions or is negatively influenced by political and economic considerations in the exercise of its responsibilities The media has a great role to play in deepening the linkages in the social structure to enhance communication towards inclusive participatory decision processes that satisfy the public good, and in the creation of a collective conscience for national integration and societal cohesion. But the immersion of the media in fundamental problems that afflict the society raises serious questions about the preparation of the media to be a change agent in its defining responsibility to (re)invent a democratic and inclusive society.

In addition, there is a growing perception in the public space that the media usually report corrupt practices in government when those in government or close to the government instigate them to report incidences of corrupt practices amongst public officials. The problem with the media in its report on corruption amongst public officials in Nigeria is that such report is often instigated by those in government to settle political scores; and not essentially to strengthen the institutions of the government or enhance the processes of building an inclusive society. It is not unlikely that the usual reluctance of the government to punish public officials whose names have been mentioned in the media for corruption related cases suggest the little confidence government leaders have in the media. For example, the reluctance of the President Muhammad Buhari's government to disengage the former Secretary to the Government of the Federation, Babachir Lawal, after he was indicted by a presidential panel that established inappropriate conduct against him in the misuse of public funds meant for those displaced as a result of insurgency by Boko Haram and the grudging way the former finance minister, Kemi Adeosun, was forced to resign after she was found not to have done the mandatory National Youth Service in requirement for those who would want to occupy public office lend some credence to this growing belief. It took months before the government could take a decision on both cases that demonstrated a flagrant violation of public office and trust that was insistently reported by a section of the media.

\section{Governmental Regulatory Controls and License Registration as Factors That Impose Censorship on the Media in Nigeria}

\subsection{Issuance of Media License and Registration}

This is one of the most critical factors that government deploys in the control of the media. Section 9(1) of the Nigerian Broadcasting Commission (NBC) outlines the criteria the Commission uses in granting broadcast license. If the NBC is satisfied that the corporate body has met its requirements, it makes recommendation through the Minister of Information to the President for the approval of license. This reveals that the NBC is not independent and its decisions may not be insulated from the political considerations of either the Minister or the President who can set aside its decisions. Beyond the fact that the Director General of the NBC is an appointee of the President, the President reserves the exclusive authority to approve or disapprove the decision of the NBC.

In light of this background, government could at the point of registration determine if those who are behind the formation of the media platform are friends and allies or perceived adversaries of the government. There is always a reluctance to issue media license to those the government perceives to be its adversaries or friends to those in the opposition. Usually, those in government tend to frustrate the process of securing license by using the instrumentalities of the state to either deny them registration or frustrate them. For example, government could make the cost of registration extremely prohibitive and the procedures cumbersome for those who are considered adversaries. Aside the high cost of registration, the duration of five years license not only creates a problem for the media house to recoup its investment but also compels it to adopt commerce as a means of surviving the inclement conditions of the environment in which it operates. For example, the use of adverts, sponsored advertorials and editorials destroys one of the core responsibilities of the media to educate and inform the citizens. In recognition of these issues, the African Commission on Human and People's Rights has drawn attention to the dangers that high cost of registration as a precondition for the registration of media houses poses for freedom of expression [16]. This problem is not peculiar to the developing countries. Indeed a 2010 study of regulatory practices in over one hundred 
countries that comprised both developed and developing countries have found that in one out of every four countries, government has a critical role in licensing and in the approval of who can work as a journalist. Sometimes the government could also deny journalists and media platforms that are critical of its policies to cover the activities of the government. On November 7, 2018, in the United States which is usually considered the bastion of democracy, former President Donald Trump suspended the press pass of CNN correspondent, Jim Acosta, over a heated confrontation during a news conference on an issue relating to the caravan of migrants from Latin America that was heading towards the southern border of the United States. CNN had to sue President Trump and the White house before its reporter was recalled. This is to demonstrate that government is always intolerant to media houses that have chosen the path of professionalism. At the other extreme, government tends to facilitate the issuance of license and registration to those who enjoy its confidence and would expectedly support the government, launder its image and give popularity to its programmes.

For existing media outfits, they rarely expose corrupt practices in government for the fear that they do not want to incur the wrath of the government and sometimes for strategic reasons associated with/to market and profit interest. This is another form of political corruption on the part of both the government and the media. This development skews the media to perverse its responsibilities to lend undeserving support to a government that is disconnected from the people it governs. In this context, the media shirks its responsibilities to inform and educate the citizens. This internal unregulated censorship is a common feature of media organisations whose patrons/founders have cosy relationship with those in government.

\subsection{Ownership of Media Houses}

The ownership of media houses poses another problem for press freedom in Nigeria. A considerable number of politicians or their cronies own media houses in Nigeria. Usually, these media houses carry out their responsibilities to accommodate the preferences and sensibilities of their owners with little or no consideration for their professional ethics and responsibilities to the society. In some instances, media owners influence the editorial decisions of their newspapers to ensure their economic and political interests are protected. A classic example happened during the military regime of General Ibrahim Babangida when Labaran Maku, who later became the Minister of Information under President Goodluck Jonathan, wrote a damning story against the Babangida's government. His employer and owner of Champion Newspaper, Chief Emmanuel Nwayanwu, had to disengage his service for writing a scathing story that was considered too critical of the Babangida's government. Also, the premises of The Guardian Newspaper were sealed by the military regime of Generals Ibrahim Babangida and Sanni Abacha for its scathing criticism of those regimes. The News Magazine had its editors jailed and the newspaper was proscribed by the military junta of General Ibrahim Babangida for its consistent and blistering criticism of the regime's feeble commitment to the restoration of civil rule and consequent annulment of the June 12 election. The Concord Newspaper also had its license withdrawn for the legitimate expression of sympathy for its founder and acclaimed winner of the annulled June 12, 1993 election that was won by the late business tycoon turned politician, Chief Moshood Kashimawo Abiola. These examples are relevant to underscore the courage of the media during the military regime and the arbitrariness of the government to clamp on the media.

\subsection{Political Affiliation of the Media}

This is more of a self-inflicted problem. The partisan disposition of those who own media houses also account for the corruption in the media. This is manifested in the way information is either distorted or suppressed by the media for political reasons. For example, there is a strong perception that African Independent Television (AIT) is sympathetic to the opposition People's Democratic Party (PDP) that ruled the country from 1999 to 2015. This is because the AIT is owned by Chief Raymod Dokpesi, a prominent member of People's Democratic Party. On the other hand, Channels Television owned by former National Television Authority ace broadcaster, John Momoh and TVC rumoured to be owned by the ruling All progressive Congress APC national leader, Asiwaju Bola Ahmed Tinubu, are perceived to be friendly to the ruling APC government. Indeed, it is a popular belief that Channels TV Chairman and Chief Executive Officer, John Momoh, was made the Chairman of Broadcasting Corporation of Nigeria (BON) in compensation for the role Channels TV played when the ruling party was in the opposition prior to 2015. Incidentally, The Nation Newspaper that is owned by the All Progressive Congress (APC) National Leader, Asiwaju Bola Ahmed Tinubu, has suddenly become so timid in criticizing the APC led federal government of Muhammad Buhari. This is the extent to which the ownership of the media could constrain the media from carrying out its functions diligently.

\subsection{Right to Access}

The right to information has been circumscribed by the level of urbanization and class related factors. For those who stay in the urban centres such as the cities and big towns, residents of such locales have found it relatively easier to access information from the media than those who stay in rural areas where social facilities are either lacking or nonexistent. Those in the urban centres enjoy cable and satellite television and readily access information that are provided by the world wide web of the internet via electronic dissemination of information. Those who stay in rural areas are very constrained in their access to information as they rely mostly on government-controlled media to get information on the radio. In most cases, the information they get from government-controlled radio stations are heavily censured to protect and enhance the interest of those who control and leverage on the government. Incidentally, most of those who reside in rural areas are financially disempowered 
to subscribe to over-the -air and cable television. Even in urban centres and cities, illiteracy and poverty have been key factors that determine accessibility to the quality of information that residents receive. Accessibility to information is determined by the social status of those who stay in cities and urban centres. The poor in urban centres are so much overwhelmed by existential challenges that they hardly think about information. In instances where they do, they can only afford to subscribe to channels of information that are mostly controlled by the government.

\section{The Media, Democracy and Good Governance}

The core responsibilities of the media are to check the government, provide objective information to the citizens, stir public debate and expose the ills in the society. In a global-modern world, the media is to educate citizens and empower them to evaluate government policies, raise the consciousness of the citizens to make an informed decision during elections and expose corruption in both the public and private spheres. This is why [17] argued that an important characteristics of modernity is that the media must impact on the culture and public mentality of citizens. It is important to appreciate that the media is important to the way in which the collective thinking and world view of people are not only formed but framed for the understanding and interpretation of social realities. The media is seen as not only reflecting a social reality but could also create a simulated social world that might displace the "real world" in the consciousness of the people. The contribution of the media to the way in which people perceive and interpret social reality and sometimes throw up a simulated imaginary social world that replaces the actual real world cannot be ignored. For example, the issue of identity construction has been so elevated to a critical level by the media in Nigeria considering the fact that the media has become "...the primary source of images of social reality and materials for forming and maintaining social identity"[2]. For example, the significance that people attach to a simulated ethnic social world seems to account for the virulent activities of separatist movements that questions the existence of the Nigerian nation. Media representation of an imaginary ethnic social world has eroded the confidence and loyalty that people have for the country, and have fuelled the developments of centrifugal groups that offer ethno-religious narratives as solutions to the problems that bedevil the Nigerian society. This is evident in the proliferation of separatist movements like Oduduwa movement, Indigenous People of Biafra, Arewa Youth Congress, Ijaw National Youth Council and a host of other centrifugal movement whose activities have been given visibility by the media. Thus, the media could create a context and an experience in which people think they are contributing to meaningful public life through an activity that questions the real world.

On the issue of good governance, it is important to aver that there are no precise standard frameworks to determine good governance. Nonetheless, there is consensus that the media is critical to the process of engendering good governance. There are concrete indicators for measuring what constitute good governance. [18] identified five indicators of good governance, namely, accountability, lack of corruption, transparency, efficiency and effectiveness, consensus and inclusiveness. The indicators that are left out in Norris's characterization are: vibrant and independent media, strong civil society and strict adherence to the principles of separation of powers and the rule of law. In other to achieve good governance, the media have a central role to play in raising conversations around the nation building project with a view to building an inclusive, just and democratic society. The media also has a responsibility to tone down issues that would not promote good governance, national integration and corporate existence. The media has some limitations in this direction. The media has become enthralled in ethno-religious colourations of social problems that bedevil Nigeria. This is a disservice that the media has rendered to the process of resolving the fundamental problems in which the Nigeria state is immersed.

It is improbable for democracy to be nurtured when the media is ineffective and inefficient in reporting the activities of the government, in exposing corruption in the public sphere, and in educating citizens about government policies. The four fundamental responsibilities of the media to the government and the society identified by [19] namely, (1) providing the platform for the discussion of plural, usually conflicting ideas; (2) offering an expression of voice for public opinion; (3) serve as citizens eyes and ears to survey the (in)actions of government and the performance of politicians; and (4) act as the public watchdog that barks at the misdemeanour and corruption of those in government. Without an independent and vibrant media, the abuses of power in the chambers of the government would remain a defining feature of governance. If the heart of democracy underscores the accountability of the government to the people, the media must be the defining institution that would provide the anchor.

\section{Recommendation for further studies}

In light of the crucial nature of the media to a country that is gripped by capitalism and the forces of globalisation, it is important that future research should be directed at investigating how globalization has affected the core responsibilities of the media to the government, the citizens and the society. In other words, has globalization led to the redefinition of the roles of the media? Such academic effort must dwell on the interface between globalisation and the media, and how core democratic culture could be activated among the citizens to deepen democracy and engender good governance? This direction for future research becomes compelling to enable the media create a healthy society that provides a context for it to function optimally and efficiently in the discharge of its responsibilities, and to also enable citizens rise above the cleavages and divides of a heterogeneous society and the challenges associated with a fledgling democracy. The description above for future research captures the leitmotif of the media in the context of 
challenges posed by globalisation to the Nigerian society, media and governance.

\section{Conclusion}

In conclusion, if democratisation is not limited to the process in which democracy is transculturated [20] but also includes the "...equitable reconstitution of the power structure" [4], then the media must become an indispensable component and driver of such a defining feature that would engender justice, peaceful coexistence and good governance in the country. Without an independent and vibrant media, democracy would be imperiled and civic participation would have no meaning. It is only an independent media that can enable civic participation that provokes rationality and patriotism amongst citizens. If freedom of expression is a critical component of human development and good governance, then the media must be encouraged to carry out its duties to the society and the government without hindrance. The media itself cannot develop except there is a political will by the government, media stakeholders and the informed demography of the population to build a strong and independent media. The media must ensure it is the guardian of the public domain for the society not to degenerate into anarchy. It must neither be the lap dog of the government or the powerful affluent elite so as to be the conscience of the society. In other words, the media must be responsible in the way it exercises its responsibilities to the society and the government. Without a robust and independent media, good governance would be elusive. This is one sure reason why the media has become an issue for democratic conversation!

\section{Acknowledgements}

I acknowledge the assistance of Dr. Chido Onumah, the Coordinator of African Centre for Media and Information Literacy, an Abuja based NGO for providing the documents in the appendix.

\section{Appendix}

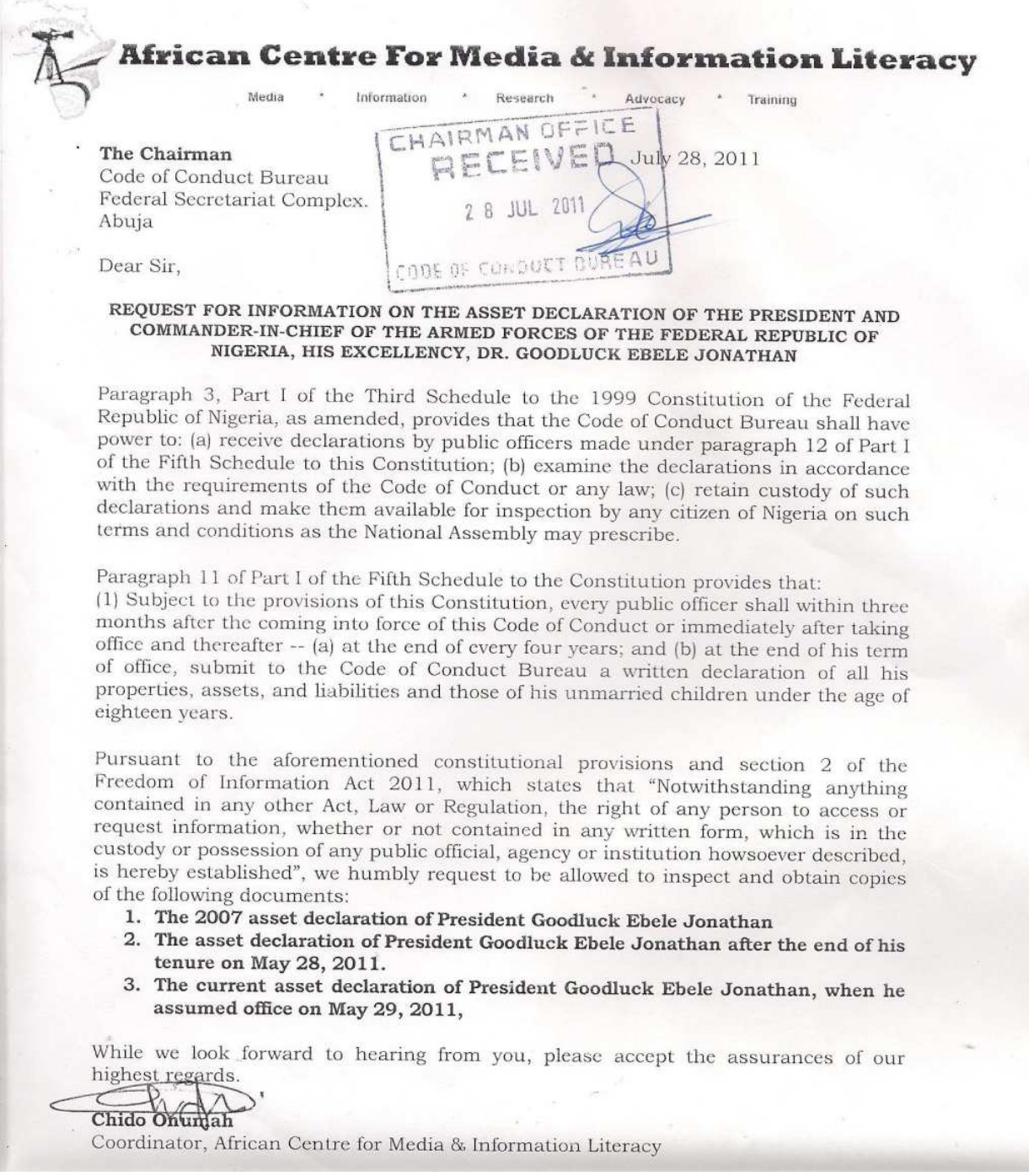




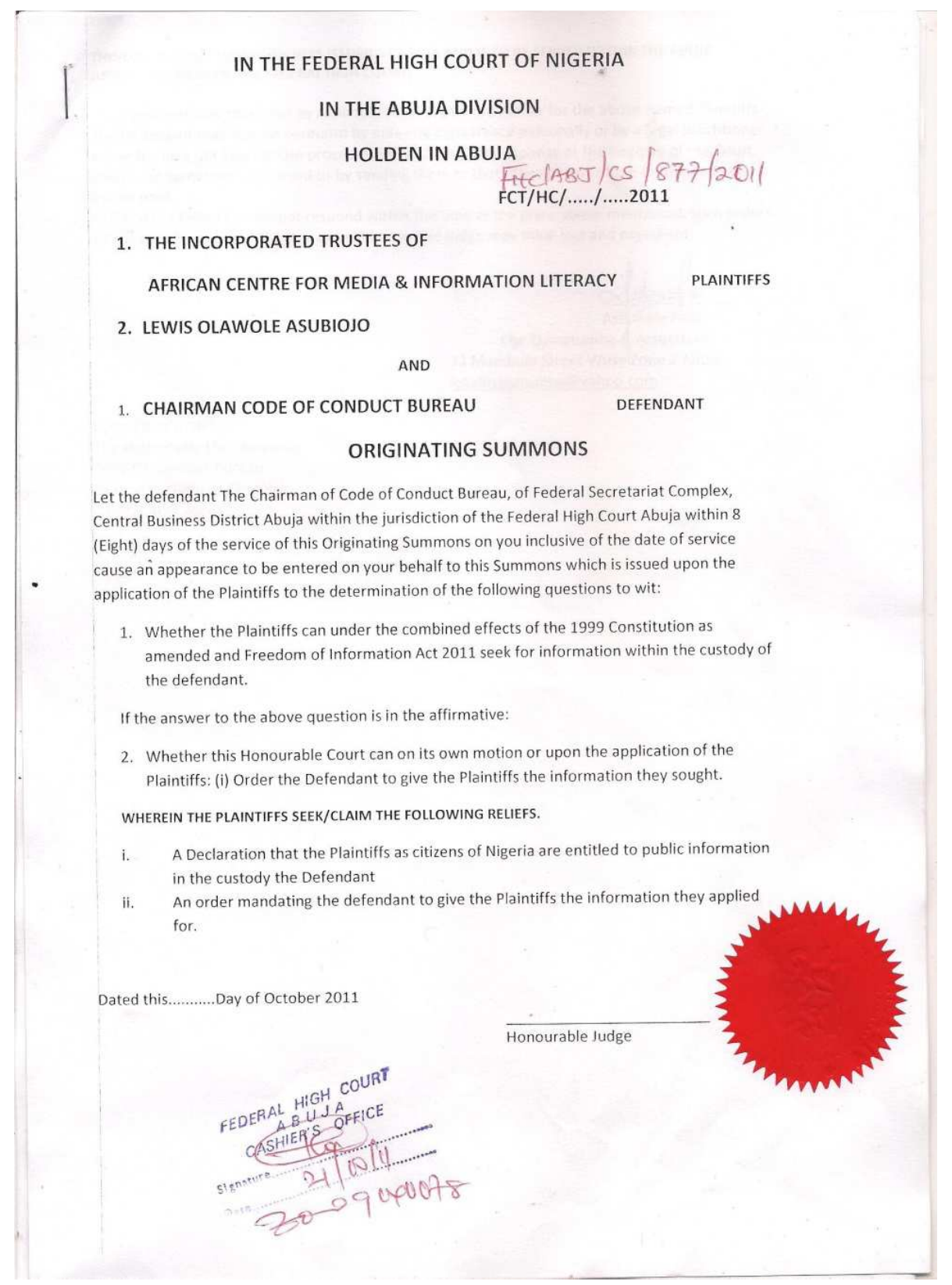

October 21, 2011

Press Release

African Centre for Media \& Information Literacy takes Code of Conduct Bureau to court over President Goodluck Jonathan's Asset Declaration.

The African Centre for Media and Information Literacy (AFRICMIL) has dragged the Code of Conduct Bureau (CCB) to court over the asset declaration of President Goodluck Jonathan. In a suit (No FHC/ABJ/CS/877/2011) filed today (October 21, 2011) at the Federal High Court, Abuja, on behalf of AFRICMIL by Ashimole Felix of Che Oyintumba \& Associates, AFRICMIL is seeking an order of mandamus compelling the CCB to comply with its request of making available to the public the asset declaration of President Goodluck Jonathan.

On July 28, 2011, AFRICMIL sent a Freedom of Information request to the CCB asking "to be allowed to inspect and obtain copies of the 2007 asset declaration of President Goodluck Ebele Jonathan; the asset declaration of President Goodluck Ebele Jonathan after the end of his tenure on May 28, 2011; and the current asset declaration of President Goodluck Ebele Jonathan when he assumed office on May 29, 2011".

According to Mr. Lewis Asubiojo, Director of Programmes AFRICMIL, the organization was concerned that even with the memo from the presidency that government agencies should subject themselves to the Freedom of Information Act, the CCB refused to act on its request. Mr. Asubiojo noted that for a government that has proclaimed a transformation agenda and wants to fight corruption, it is important that President Jonathan leads by example, and one way he can do that is to make public his asset declaration. 
Paragraph 3, Part I of the Third Schedule to the 1999 Constitution of the Federal Republic of Nigeria, as amended, provides that the Code of Conduct Bureau shall have power to: (a) receive declarations by public officers made under paragraph 12 of Part I of the Fifth Schedule to this Constitution; (b) examine the declarations in accordance with the requirements of the Code of Conduct or any law; (c) retain custody of such declarations and make them available for inspection by any citizen of Nigeria on such terms and conditions as the National Assembly may prescribe.

Paragraph 11 of Part I of the Fifth Schedule to the Constitution provides that: (1) Subject to the provisions of this Constitution, every public officer shall within three months after the coming into force of this Code of Conduct or immediately after taking office and thereafter -- (a) at the end of every four years; and (b) at the end of his term of office, submit to the Code of Conduct Bureau a written declaration of all his properties, assets, and liabilities and those of his unmarried children under the age of eighteen years.

Pursuant to the aforementioned constitutional provisions and section 2 of the Freedom of Information Act 2011, which states that "Notwithstanding anything contained in any other Act, Law or Regulation, the right of any person to access or request information, whether or not contained in any written form, which is in the custody or possession of any public official, agency or institution howsoever described, is hereby established", AFRICMIL made the request to the CCB to be allowed to inspect and obtain copies of President Goodluck Jonathan's asset declaration.

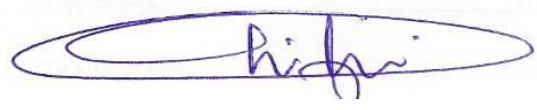

Chido Onumah

Coordinator, African Centre for Media \& Information Literacy

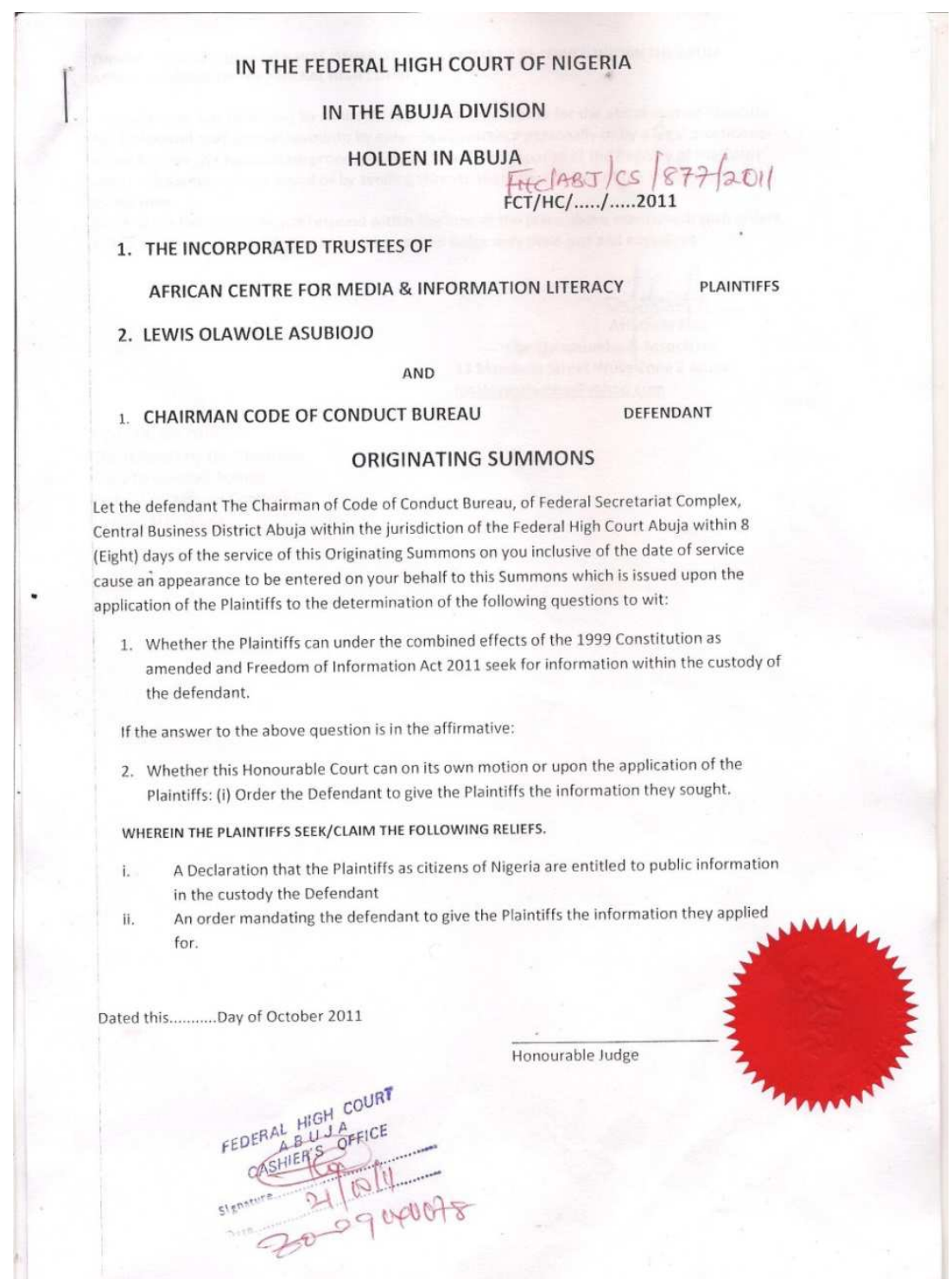




\section{References}

[1] Blumler, J. G., \& Coleman, S. (2016). Democracy and the Media- Revisited DEMOCRACY AND THE MEDIAREVISITED.3222(September).

https://doi.org/10.1080/13183222.2015.1041226 Javnost - The Public Journal of the European Institute for Communication and Culture.

[2] McQuail. (2010). McQuail's Mass Communication Theory. SAGE Publications Ltd.

[3] Kafle, H. R. (2014). Media studies: Evolution and perspectives Media studies: Evolution and perspectives. February. https://doi.org/10.3126/bodhi.v3i1.2808

[4] Ullah, M. S. (2009). Free Media, Democracy and Democratisation: Experiences from Developing Countries. Journal of Global Communication, 2 (2), 343-351.

[5] CDD. (1999). Centre for Democracy and Development Report.

[6] Ashraf, P. (2014). The Role of Media in Good Governance : Paid News Culture of Media and the Challenges to Indian Democracy. 3 (3), 41-43.

[7] Randall, V. (2007). the Third World The media and democratisation in the Third World. February 2015, 37-41. https://doi.org/10.1080/01436599308420346

[8] DFID. (2015). DFID Nigeria Efforts on Social Protection. November.

[9] Bezabih, T. (2017). Mass Media and Governance: Issues and Challenges in Contemporary Ethiopia. New Media and Mass Communication, 61, 28-33.

[10] Dalton, R. J., Farrell, D. M., \& Mcallister, I. (2011). The Dynamics of Democratic Representation: How Democracy Works. APSA 2011 Annual Meeting Paper, September 2011, $1-40$.

[11] Njemanze, N. \& Arogundade, L. (2015). (2015). Reportage of 2015 elections: A monitoring scorecard of print and online media. The International Press Council (IPC) and the Nigerian Press Council (NPC).

[12] Freille, S., Haque, M. E., \& Kneller, R. (2007). A Contribution to the Empirics of Press Freedom and Corruption A contribution to the empirics of press freedom and corruption. January. https://doi.org/10.2139/ssrn.863805

[13] Nogara, M. (2009). Role of media in curbing corruption : the case of Uganda under President Yoweri K. Museveni during the " no-party" system. 72.

[14] Grabber D. (1986). Press freedom and the general w elfare. In Political Science Quarterly (Vol. 101).

[15] Pharr, S., Putnam, R., 2000. (2000). Disaffected Democracies: What's Troubling the Trilateral Countries? Princeton University Press, California.

[16] Callamard, A. (2010). Accountability, Transparency, and Freedom of Expression in Africa. Social Research, 77 (4).

[17] Johnson, D. P. (2008). Contemporary Sociological Theory An Integrated Multi-level Approach New York: Springer.

[18] Norris, P. (2009). Critical Citizens Revisited Also from Cambridge University Press by the Author.

[19] Gurevitch M. and Blumler Jay G. (1990). Political Communication Systems and Democratization Values. In Democracy and the Mass Media by Judith Lichtenberg (pp. 269-287). Cambridge University Press.

[20] Chan, S. (2002). Liberalism, Democracy and Development. Cambridge University Press. 